grams or services offered and the local presence (and investment) by the foreign provider. Credits and qualifications are awarded by the foreign provider (through foreign, local, or selfaccreditation methods) or by an affiliated domestic partner or jointly. The key question remains who monitors and recognizes the "legitimacy" and "recognition" of the qualification for future study and employment purposes. The forms of crossborder provider mobility include branch campuses, merger with or acquisition of domestic providers, independent institutions, study and support centers, virtual delivery, plus other types of innovative affiliations. A distinguishing feature between program and provider mobility is that with provider mobility the learner is not necessarily located in a different country than the awarding institution as is the case with program mobility; and this raises other issues and challenges.

\section{Academic Corruption: The Continuing Challenge}

\section{Philip G. Altbach}

Philip G. Altbach is Monan professor of higher education and director of the Center for International Higher Education at Boston College.

$\mathbf{T}^{\mathrm{f}}$ the spate of news reports about corruption in higher edu1 cation indicates the scope of the problem, the world is seeing a dramatic increase in the phenomenon. Not only is corruption undermining the core values of higher education in some parts of the world, it is creating problems of credibility as societies link universities with unsavory practices. After all, higher education's bedrock mission consists of the pursuit of knowledge and truth. Universities worldwide have long claimed special privileges of autonomy, academic freedom, and support by society precisely because of their devotion to the public good and their reputations for probity. They have long enjoyed high social prestige precisely for these commitments. If universities lose their standing in society as special institutions, they will suffer unparalleled damage.

\section{Stories of Corruption}

Here is a sampling of current press reports on academic corruption. These stories provide a sense of the scope and variety of the problem worldwide.

Russia is introducing a national entrance test for university admissions, in considerable part because of perceived corruption in the traditional entrance system. Russian families pay about $\$ 300$ million annually in bribes to ensure acceptance to universities, and another $\$ 700$ million once students are enrolled. A former deputy prime minister put the amount spent on academic bribes at between $\$ 2$ and $\$ 5$ billion a year. Family and political connections account for further corruption in the entry process. The test, it is hoped, will eliminate subjectivity in admissions, allowing meritocratic decisions and also better access for applicants from outside the major cities. The point here is that corruption is seen as so endemic to the system that a major reform had to be implemented in an effort to curb it.

The admissions process involves a lot of corruption because of the coveted nature of access to higher education, especially to the most prestigious universities. With its long history of competitive and highly regarded national examinations for admission to many of its universities, China recently suffered an admissions scandal covered in the national media. University officials demanded a payment of \$12,000 from a student whose test score qualified him for admission to a prestigious university. One critic noted, "Over the past few years, we have been trying to marketize higher education and turn it into an industry...but whenever money is involved in anything, there will be problems." The press reported that this case is "just the tip of the iceberg."

\section{The admissions process involves a lot of corrup- tion because of the coveted nature of access to higher education, especially to the most presti- gious universities.}

The University of Port Harcourt, in southern Nigeria, recently revoked the degrees of 7,254 of its graduates in a crackdown on academic fraud. The head of the university charged students stripped of their degrees with either cheating on examinations or falsifying their academic records, in cases going back to I966. He characterized Nigerian universities as rife with corruption, with many students being admitted with false secondary school certificates. A report by the Exams Ethics Project, a nongovernmental organization, noted that, "Academic fraud and corruption is a big business in Nigeria."

In South Korea, the government demanded that three private universities fire 68 faculty members and administrators, on charges of embezzlement, mismanagement of funds, and bribery. Investigators found that one school diverted $\$ 4.9$ million to personal use and illegally redirected another $\$ 4.6$ million.

\section{Why Now?}

The current focus on corruption in higher education indicates the prevalence of the problem-although the phenomenon is by no means unprecedented in history. While we have no way of knowing if academic corruption is in fact more widespread than in earlier times, it is certainly attracting more attention. One can pose several hypotheses as to why there seems to be more corruption.

The greater scrutiny of academic institutions relates to higher education's high profile for providing social mobility. A successful career requires an academic degree, even if obtained fraudulently or from a "degree mill." As a result, academe attracts more attention, and more criticism, from the mass 
media. And it is under greater pressure to provide both the access and the certification that are essential for success.

Furthermore, as higher education has "marketized," it adopted more and more commercial values, including a greater predilection for corruption, and a greater distance from traditional academic values.

A related phenomenon is the massification of higher education. Many newer mass higher education providers, not only universities but also commercial enterprises offering postsecondary qualifications, also have only marginal connections to core academic values.

The deterioration of the idea of higher education as a "common good" has created unprecedented pressures on academe. Around the world, the state has withdrawn support from higher education. Even the most prestigious universities have had to be more concerned with the "bottom line." Commercial considerations loom ever larger in academic affairs. Few institutions know how to ensure adequate income in this new environment, and some have been lured into engaging in corrupt practices.

\section{The deterioration of the idea of higher education as a "common good" has created unprecedent- ed pressures on academe.}

Professors and administrators, faced with deteriorating salaries and working conditions, in some cases are taking part in corruption. A growing number of part-time and poorly trained regular faculty are especially prone to corruption. They lack an understanding of the meaning of the traditional university as well as the means to support themselves with their academic salaries.

New providers of higher education, including business enterprises and some for-profit academic institutions, have little understanding of academic values. They are in the higher education business exclusively to earn money. As traditional universities with inadequate management skills partner with these new providers, there is a clash of cultures and possible corruption.

The Internet, another area of potential problems, constitutes an untamed frontier filled with all kinds of academic offerings, from worthless degrees that can be purchased and unregulated academic programs from a diverse range of providers to a few thoughtfully designed programs offered by respected universities. There is great latitude for shady practices.

Corruption and related ethical problems present an unprecedented threat to higher education. The loss of higher education's objectivity, honesty, and high ethical standards would remove the central rationale for public support. The growing number of bad apples in the barrel is threatening the entire academic enterprise.

\section{World Class Universities:}

\section{American Lessons}

\section{Charles M. Vest}

Charles M. Vest is president of the Massachusetts Institute of Technology and author of Pursuing the Endless Frontier: Essays on MIT and the role of Research Universities (MIT Press).

Tn its new ranking of the world's 200 best universities, The 1 Times Higher found the top three to be U.S. institutionsHarvard University, the University of California, Berkeley, and the Massachusetts Institute of Technology.

There are good reasons why U.S. universities fare well in competitive rankings, and other nations could profitably consider the structural and policy factors that help them achieve such heights.

But collaboration may be even more profoundly important than competition in determining the future of higher education. Indeed informal global cooperation is already beginning to create the meta-university that will see the best scholarship and teaching shared worldwide.

The factors I believe contribute the most to the excellence and competitive success of US higher education include:

- The diversity of institutions-from small liberal arts colleges to large public and private universities-allows students to select the school that best matches their needs

- New assistant professors have freedom to choose what they teach as well as research

- Our research universities weave together teaching and research in ways that bring freshness, intensity, and renewal to both activities

- We welcome students, scholars, and faculty from abroad. Their intellectual and cultural richness help define our institutions

- Support of frontier research in our universities has long been an important responsibility of the federal government, which awards grants to researchers on the basis of their merit in a competitive marketplace of ideas

- A tradition of philanthropy, fostered by U.S. tax law, encourages alumni and others to support our colleges and universities. Scholarship funds they provide allow talented students from families of modest means to attend even the most costly schools

- Open competition for faculty and students drive excellence.

Such factors could be integrated into the cultural and political contexts of other nations and perhaps be improved on.

The enormous success and impact of the Indian Institutes of Technology, established in the I96os, demonstrate that great universities based on this research-intensive model can rise rapidly anywhere in the world. 